19 Revue d'histoire du XIXe siècle

Société d'histoire de la révolution de 1848 et des

révolutions du XIXe siècle

$12 \mid 1996$

L'incendie

\title{
Hommage à Henri Dubief (16 juin 1910-24 février 1995)
}

Maurice Agulhon and Jacqueline Lalouette

\section{OpenEdition}

\section{Journals}

Electronic version

URL: http://journals.openedition.org/rh19/91

DOI: $10.4000 /$ rh 19.91

ISSN: $1777-5329$

\section{Publisher}

La Société de 1848

\section{Printed version}

Date of publication: 1 June 1996

ISSN: 1265-1354

Electronic reference

Maurice Agulhon and Jacqueline Lalouette, « Hommage à Henri Dubief (16 juin 1910-24 février 1995) », Revue d'histoire du XIXe siècle [Online], 12 | 1996, Online since, connection on 02 October 2020. URL : http://journals.openedition.org/rh19/91 ; DOI : https://doi.org/10.4000/rh19.91

This text was automatically generated on 2 October 2020 .

Tous droits réservés 


\section{Hommage à Henri Dubief (16 juin 1910-24 février 1995)}

Maurice Agulhon and Jacqueline Lalouette

\section{ABSTRACTS}

No abstract available by now

Pas de résumé disponible actuellement

INDEX

Mots-clés: Hommage 